\title{
COMMENT
}

\section{POLICE BULLETINS AND PRIVATE SEARCHES}

Rail and air freight departments in southern California often receive police bulletins requesting them to contact the police if shipments of marijuana or other drugs are discovered or suspected. The bulletins usually request only that the private parties notify the police; but often after receipt of a police bulletin freight department supervisors on their own initiative authorize either the seizure or search of suspicious packages or of the luggage of suspected narcotics smugglers. In three recent cases, ${ }^{1}$ California courts have been asked to determine whether such searches or seizures by airline employees are police activities and thus within the purview of the fourth and fourteenth amendments. The California Supreme Court has side-stepped the issue entirely, but two California appellate courts have held that private party searches or seizures in response to a police bulletin are not subject to constitutional scrutiny in a criminal prosecution. ${ }^{2}$ In People $v$. $M c$ Frew, $^{3}$ an airline employee, suspicious of McGrew's long hair, nervous demeanor, and heavy footlocker, broke open the locker on the

1 Abt v. Superior Court, 1 Cal. 3d 418, 462 P.2d 10, 82 Cal. Rptr. 481 (1969) (en banc); People v. McGrew, 1 Cal. 3d 404, 462 P.2d 1, 82 Cal. Rptr. 473 (1969) (en banc); People v. Temple, 80 Cal. Rptr. 885 (1969).

2 In People v. McGrew, 1 Cal. 3d 404, 409, 462 P.2d 1, 4, 82 Cal. Rptr. 473, 476

(1969) (en banc), the California Supreme Court stated:

We find it unnecessary to determine whether Dowling, the United Airlines employee, must be considered an agent of the police in opening the footlockers because, even assuming that he was not, the subsequent searches by law enforcement officers or at their express and specific direction . . . were unlawful and the evidence must be suppressed.

With nearly identical language the court disposed of the same issue in Abt v. Superior Court, 1 Cal. 3d 418, 421, 462 P.2d 10, 11, 82 Cal. Rptr. 481, 483 (1969).

But a California court of appeal, People v. McGrew, 75 Cal. Rptr. 378, vacated, 1 Cal. 3d 404, 462 P.2d 1, 82 Cal. Rptr. 473 (1969) (en banc), squarely faced the issue and found Dowling to be acting independently of the police and the search therefore not subject to fourth and fourteenth amendment prohibitions. A different California court of appeal reached a similar conclusion in People v. Temple, $80 \mathrm{Cal}$. Rptr. 885 (1969).

375 Cal. Rptr. 378, vacated, 1 Cal. 3d 404, 462 P.2d 1, 82 Cal. Rptr. 473 (1969) (en banc). The headnote to the appeliate court decision indicates that the case was decided on Feb. 17, 1969, and that a hearing was granted on Apr. 30, 1969. The California Court Rules permit the supreme court, within 30 days after a decision of a court of appeal becomes final as to that court, to transfer the cause, either on its own motion or on petition by a party, for hearing and decision. CAL. S. Cr. \& APP. (CIV. \& CRIM.) R. 28(a) (Supp. 1970). The supreme court for good cause may extend the period up to an additional 60 days. Id. A decision of a court of appeal becomes final as to that court 30 days after filing. Id. 24(a). Thus the supreme court heard the state's appeal from the trial court's order to suppress exactly as did the court of appeal. The latter court reversed, but the supreme court affirmed, thereby vacating the court of appeal decision. As pointed out above, however, note 2 supra, the supreme court effectively skirted the issue whether the airline employee was acting as an agent of the police. 
advice of the freight supervisor and discovered marijuana. ${ }^{4}$ The police bulletin in People $v$. Temple ${ }^{5}$ contained a detailed description of the suspected trunks, including their size, weight, and probable destination, and a photograph of a similar recently seized trunk. ${ }^{6}$ The freight supervisor withheld Temple's trunks from their scheduled flight ${ }^{7}$ and called the police, who searched the trunks without a warrant and seized eighteen or nineteen bricks of marijuana from each trunk. The court's reasoning in Temple is representative of the appellate court's in $M c G r e w$ :

[T] he mere fact that the police bulletin requested freight employees to contact police when seeing trunks of the type it depicted and that one agent (and so probably others) had been encouraged by UAL [United Air Lines] to cooperate with law enforcement did not make the UAL personnel agents of the police and did not make the temporary diversion of the trunks from the scheduled flight a police activity. . . . The temporary diversion of the trunks was the air freight supervisor's own idea and a private act. . . . There was no directly joint action of the type present in Stapleton v. Superior Court ... There is, certainly, a line to be drawn between joining the police in a specific investigation already launched by them and making a simple response to a general request for cooperation in detecting crime, a badge of good citizenship. ${ }^{8}$

This Comment, however, will argue that the nature of the relationship between the police and the freight supervisors in Temple and McGrew required that the supervisors' acts be deemed police activity and therefore subject to the fourth and fourteenth amendments. The Comment will also propose tests hopefully helpful in deciding when a private citizen's activity induced by police request is, in fact, police activity.

4 Similar facts arose in Abt v. Superior Court, 1 Cal. 3d 418, 462 P.2d 10, 82 Cal. Rptr. 481 (1969), decided the same day and in substantially the same fashion as McGrew. In McGrew it is unclear whether the freight department ever in fact received a police bulletin immediately prior to the search. The employee had been alerted by his superiors to watch for heavy new footlockers, and had heard "scuttlebutt" that the warning originated with the Honolulu police. The trial court found that the warnings had come from the police, but the court of appeal was sceptical and declared the origin of the warnings immaterial. 75 Cal. Rptr. at 379-81.

580 Cal. Rptr. 885 (1969).

${ }^{6}$ Id. at $890-91 \mathrm{n} .9$ (partial text of police bulletin).

7 The court's opinion does not state whether the trunks merely missed their scheduled flight or were intentionally diverted from it by the supervisor. Id. at 887 n.2. But the court was apparently willing to assume the latter. Id. at 889 .

8 Id. at 889-90. The court of appeal in McGrew held:

Whether the suggestion airlines be on the alert for such footlockers originated from the police is immaterial. . . The police do not necessarily make agents of citizens they warn concerning crimes. . .

.. Here Dowling did not act in a joint enterprise with, or as an agent of the governmental law enforcement agency.

75 Cal. Rptr. at 381. 


\section{Private Activity and the Fourth Amendment}

The Temple and McGrew courts attempted to establish that the activity of the supervisor in seizing the trunks was private and therefore within the well-litigated and discussed private party exception to the fourth amendment. ${ }^{9}$ The facts of Burdeau $v$. $M c$ Dowell, ${ }^{10}$ the Supreme Court's forum for announcing the exception, provide a typical illustration of the type of private activity exempted. In Burdeau, private parties, independent of police suggestion, stole incriminating evidence from a safe and turned it over to the government authorities. Refusing to require the return or exclusion of the evidence, the Court said:

[T] he record clearly shows that no official of the Federal Government had anything to do with the wrongful seizure of the petitioner's property, or any knowledge thereof until several months after the property had been taken from him

The papers having come into the possession of the Government without a violation of petitioner's rights by governmental authority, we see no reason why the fact that individuals, unconnected with the Government, may have wrongfully taken them, should prevent them from being held for use in prosecuting an offense where the documents are of an incriminatory character. ${ }^{11}$

9 See, e.g., Burdeau v. McDowell, 256 U.S. 465 (1921) ; Watson v. United States 391 F2d 927" (5th Cir.) (per curiam), cert. denied, 393 U.S. 985 (1968): United States v. McGuire, 381 F.2d 306, 313 n.5 (2d Cir. 1967), cert. denied, 389 U.S. 1053 (1968); Gold v. United States, 378 F.2d 588 (9th Cir. 1967); Gandy v. Watkins, 237 F. Supp. 266 (M.D. Ala. 1964), cert. denied, 380 U.S. 946 (1965) ; Geniviva v. Bingler, 206 F. Supp. 81 (W.D. Pa. 1961); People v. Randazzo, 220 Cal. App. 2d 768, 34 Cal. Rptr. 65 (1963), cert. denied, 377 U.S. 1000 (1964); State v. Holliday, 169 N.W.2d 768 (Iowa 1969)'; Sackler v. Sackler, i6 App. Div. 2d 423, 229 N.Y.S.2d 61 (1962). The exemption of private searches from the fourth amendment has been criticized extensively. See Black. Burdeau v. McDozvall [sic]-A Judicial Milepost on the Road to Absolutism, 12 B.U.L. Rev. 32 (1932); Note, Seizures By Private Parties: Exclusion in Criminal Cases, 19 Stan. L. Rev. 608 (1967) ; 63 Colum. L. REV. 168 (1963); 19 DRAKE L. REV. 476 (1970); 44 N.Y.U.L. REv. 206 (1969); 12 U.C.I.A.I. REV. 232 (1964); 3 U. SAN FRAN. I. REV. 159 (1968); 1966 UTAF

L. REv. 271.

10256 U.S. 465 (1921).

11 Id. at 475-76. The private activity in cases adhering to Burdeau's reasoning follow a discernible pattern clearly distinguishable from the private activity in Temple and $M c G r e w$. In the Burdean line of cases, the police neither requested nor expected that evidence would be wrongfully taken from the defendant. See, e.g., Barnes v. United States, 373 F.2d 517 (5th Cir. 1967) (search of travel case at initiative of motel owner); Geniviva v. Bingler, 206 F. Supp. 81 (W.D. Pa. 1961) (robbery from Geniviva provided IRS evidence to determine the correctness of his tax returns); People v. Randazzo, 220 Cal. App. 2d 768, 34 Cal. Rptr. 65 (1963), cert. denied, 377 U.S. 1000 (1964) (search by clothing store detective by looking under dressing room curtain to catch shoplifters); State v. Holliday, 169 N.W.2d 768 (Iowa 1969) (telephone company received customer complaint of threatening phone calls, recorded numbers dialed from defendant's phone); Sackler v. Sackler, 16 App. Div. 2d 423, 229 N.Y.S.2d 61 (1962) (search by husband to gain evidence against wife in divorce proceeding). See also United States v. Goldberg, 330 F.2d 30 (3d Cir.), cert. denied, 377 U.S. 953 (1964). 
But an illegal search by a private party may be subject to the exclusionary rule if the act is in fact attributable to some governmental association. For example, in People v. Tarantino, ${ }^{12}$ the police paid and instructed a private citizen to "bug" the defendant's apartment. The California Supreme Court found that the citizen was an employee of the police and that his activities were subject to fourth amendment prohibitions. If a private party is not paid by the police but acts nevertheless at their instance and under their instruction, his activity is police activity. ${ }^{13}$ "Joint action" by the police and a private party is also police activity. In Stapleton v. Superior Court, ${ }^{14}$ distinguished in both Temple and McGrew, the police and private credit card agents carefully planned a joint raid to arrest the defendant. The credit card agents searched the defendant's car in the course of the raid. The California Supreme Court, excluding the evidence of the illegal search, stated:

The search of petitioner's car was clearly part of a joint operation by police and the credit card agents aimed at arresting petitioner and obtaining evidence against him. This official participation in the planning and implementation of the overall operation is sufficient without more to taint with state action the subsequent acts of such credit card agents. ${ }^{15}$

Even mere police presence at or foreknowledge with acquiescence in a search or seizure by a private party will make the private acts police acts. $^{16}$

1245 Cal. 2d 590, 290 P.2d 505 (1955).

13 See, e.g., Corngold v. United States, 367 F.2d 1 (9th Cir. 1966) (police at airport requested that airline employees open a specific package); People v. Fierro, $236 \mathrm{Cal}$. App. 2d 344, 46 Cal. Rptr. 132 (1965) (specific request by police that hotel manager go to defendant's room and seize samples of narcotics).

1470 Cal. 2d 97, 447 P.2d 967, 73 Cal. Rptr. 575 (1968).

15 Id. at 100, 447 P.2d at 969, 73 Cal. Rptr. at 577 (footnote omitted). Stapleton also suggests that the cases construing the phrase "under color of law" may be useful in determining when the activities of a private citizen in conjunction with the police are attributable to the police. Id. at $101-02,447 \mathrm{P} .2 \mathrm{~d}$ at $970,73 \mathrm{Ca}$. Rptr. at 578 ; see United States v. Guest, 383 U.S. 745, 755-56 (1966):

This is not to say, however, that the involvement of the State need be either exclusive or direct. In a variety of situations the Court has found state action of a nature sufficient to create rights under the Equal Protection Clause even though the participation of the State was peripheral, or its action was only one of several co-operative forces leading to the constitutional violation.

16 See Stapleton v. Superior Court, 70 Cal. 2d 97, 103, 447 P.2d 967, 970-71, 73 Cal. Rptr. 575, $578-79$ (1968) ("[T] he police need not have requested or directed the search in order to be guilty of 'standing idly by'; knowledge of the illegal search coupled with a failure to protect the petitioner's rights against such a search suffices."); Moody v. United States, 163 A.2d 337 (D.C. Ct. App. 1960) (police accompanied victim of a theft to the apartment of the defendant where the victim recovered stolen goods, later introduced as evidence) ; State v. Scrotsky, 39 N.J. 410, 189 A.2d 23 (1963). In United States v. Goldberg, 330 F.2d 30 (3d Cir.), cert. denied, 377 U.S. 953 (1964), holding that, because the police believed that the evidence they requested was already in the informer's hands, the Government did not invade the defendant's privacy when the informer thereafter stole the evidence, the court implied that, had the Government known that the informer would steal the evidence, governmental action would have been found. But see note 30 infra. 


\section{Police Bulletins}

\section{A. A Test for Substantial Police Relationship}

Private activity in response to police bulletins falls between the clear cases of police-requested activity and purely private acts. As Temple and $M c G r e z e$ emphasized, the police are not initially aware that a particular act has been performed in response to their bulletin. ${ }^{17}$ The acts of the freight supervisors in the two cases were done without police planning, presence, foreknowledge, or direct supervision. But unlike Burdeau and its progeny, ${ }^{18}$ police bulletins may motivate private persons to take steps to aid the police in gathering information; and the police expect bulletins to induce individuals to obtain information in the future, while in Burdeau the police requested information already in the hands of the private party. The balance may be struck between private and police activity by attributing the private citizen's acts to the police whenever the acts, other than the mere calling of the police, would not have occurred but for the police request.

Thus a bulletin requesting a private party to inform the police whenever he may come across criminal activity would not make the recipient a police agent when relaying information he would have gathered in the absence of the bulletin. But when the bulletin requests the private party to do something beyond the scope of his normal duties or activities (for example, to detain or open a particular trunk scheduled for a particular flight), or when such unusual activity is induced because of the bulletin, then the additional action may be treated as state action. ${ }^{19}$ In United States $v$. Small, ${ }^{20}$ the police suspected that drugs were being stored in subway lockers, and asked a subway locker inspector to call them if he found any contraband drugs in the course of his inspections. ${ }^{21}$ The inspector continued to inspect the lockers at his regular pace, reaching an individual locker about once every two weeks. In the course of his inspections he opened a brown paper bag which he believed contained food but in fact contained marijuana. He notified the police by telephone and, because he could not stay by the locker until the police arrived, suggested that he change the lock on the locker. The police agreed. The court held the inspector to be a police agent when the lock was changed although not when he initially opened the locker.

The inspection of the locker by Fortune [the inspector] was conducted in the ordinary course of the Company's business, and in the exercise of the right of inspection it reserved. The mere receipt by Fortune of the telephone call from the Cambridge Police did not, under the facts established, make For-

1780 Cal. Rptr. at 889-90; 75 Cal. Rptr. at 381.

18 See note 11 supra.

19 See text accompanying notes 31-37 infra.

20297 F. Supp. 582 (D. Mass. 1969).

21 The request was made by telephone rather than by written police bulletin. 
tune their agent. . . . Fortune's inspection of the locker's contents, which he determined included marihuana, rises no higher than an observation of what was believed to be contraband by a citizen who had the right to be where he was, and was not the act of a law enforcement agent. When, however, he changed locker 725's lock, he did so, acting not within the course and scope of the Company's business, but pursuant to [the police's] request ....22

A similar result might have been reached had Fortune broken with his schedule after the police request and searched every locker every day, if possible. Such extraordinary activity might easily be attributed to his desire, stimulated by the bulletin, to aid the police in discovering evidence of crime.

The test, then, is essentially one of causation : but for the bulletin (or police request in any form), the private activity would not have occurred. Of course, determinations of causation are often difficult. In the hypothetical above, the inspector may have abandoned his usual schedule for any number of reasons-perhaps to protect more effectively against the damages caused by decaying food in the lockers. But absent any other apparent reasons for the activity, it may be presumed that the activity was undertaken in response to the police request if it would benefit only the police. The reasoning of the court in Small and of the trial court in McGrew suggests this technique of presuming causation after the receipt of the request. In Small, the locker company had no interest in changing the locks. In $M c G r e w$, the trial court suppressed the evidence largely because the airline employee acted solely for police purposes when he opened the suspicious baggage. ${ }^{23}$ Although the airline had reserved the right to inspect shipments under particular circumstances, ${ }^{24}$ it had no interest in searching trunks for suspected contraband. In both cases, because no interest of either employer or employee could be served by the extraordinary action, it may be presumed that the actions were induced by the police request for surveillance. ${ }^{25}$

22297 F. Supp. at 585. Although Fortune suggested the change, the police acquiesced in it. See cases cited note 16 supra.

231 Cal. 3d at 409, 462 P.2d at 4,82 Cal. Rptr. at 476.

24 Id. at 408, 462 P.2d at 3, 82 Cal. Rptr. at 475 (for example, "for improperly declared goods going at a cheaper rate").

25 In nearly all the cases in the Burdeau line, the evidence was not seized solely for police purposes. See cases cited note 11 supra. This police purposes test does not stand independent of the "but for" test. If a citizen, without the initiative of a bulletin, seizes evidence from another citizen with the sole purpose of convicting him, the evidence would not be excluded under Burdeau because the police did not request the seizure. The police purposes test serves merely as an inference to aid in making the causal link between the bulletin and the searches thereafter.

In People v. Craycraft, 1 Cal. App. 3d 947, 82 Cal. Rptr. 154 (1969), an airline employee in San Diego thought he smelled liquor emanating from a footlocker. The airline prohibits the handling of liquids because of the possible damage to other baggage. The employee opened the trunk and discovered marijuana. In such a case the initial search would be private even after the receipt of a bulletin because it was within the scope of the employee's normal duties and not induced by the bulletin. 
A similar approach was taken in Purvis $v$. Wiseman. ${ }^{20}$ A police detective seeking evidence in a narcotics case asked maids to keep separate any trash from the defendant's motel room and to bring to him homemade cigarettes or cigarette butts. There was some question whether he intended them to bring him all homemade cigarettes or just those which they would normally remove in the course of cleaning a room. The court said:

If the maids believed they were expected to remove any homemade cigarettes, wherever located, and whether or not trash, they searched the room.

Even if ... Matoon [the detective] requested the maids to remove only those homemade cigarettes that were also trash, it would not negate the element of State action. We are not concerned with what Matoon intended, but with what the maids believed. There was no need to mention homemade cigarettes before the maids entered the room. If, as a result of this designation, the maids searched Petitioner's room, their action was State action. The State, having made a search possible, may not escape the consequences by claiming Matoon distinguished between those homemade cigarettes that were trash and those that were not. ${ }^{27}$

The court then ordered that a hearing be held to determine what the maids believed.

The Purvis court said, in effect, that when a police request induces a private citizen to perform acts in pursuit of the police cause, which he would not otherwise have performed, his conduct will be imputed to the police. The literal text of the police request is not crucial: the activity induced is determinative.

But the Purvis court neglected to make one important distinction. The but for test, standing alone, is not altogether satisfactory. Had the locker inspector in Small, motivated by the police alert and intending to aid the police, searched subway riders at random and discovered narcotics, he certainly would not have been considered an agent of the police: ${ }^{28}$ Burdeau should apply unless the police have either knowledge or a reasonable expectation that private action will be taken on their behalf. The creation of a police agency must be formed in the expectations of both the principal and the agent, even if the expectations

26298 F. Supp. 761 (D. Ore. 1969).

27 Id. at 763-64 (emphasis added).

28 The difficulty with the "but for" test in determining the causation issue is well illustrated in tort law. Compare In re Polemis, [1921] 3 K.B. 560 (C.A.), with Overseas Tankship (U.K.) Ltd. v. Morts Dock \& Eng'r Co., [1961] 2 W.L.R. 126 (P.C.). 
are not verbalized. ${ }^{29}$ Thus, rather than looking to what the maids actually believed they were expected to do, the court in Purvis should have looked at what acts the police might reasonably have expected them to take in response to the request. The police should not be found responsible for unforeseeable acts resulting from idiosyncrasies or unreasonable misunderstandings. They should be accountable only for acts-even if not specifically requested-which they might reasonably have foreseen as a result of their request. ${ }^{30}$

In measuring reasonable police expectations, the frequency of police contact with a particular group is important. Numerous previous contacts might well enable the police to predict fairly accurately the character of private citizen response to police bulletins or other requests. The number of cases coming before the California courts indicates that the police should expect significantly more positive action than simple police notification from private parties in situations similar to Temple and $M c G r e w$.

Emphasis on reasonable police expectations is particularly important in view of the purpose of the exclusionary rule. Deterrence of improper police conduct will not be achieved by excluding evidence in cases in which it is unlikely that the private action taken could have been anticipated by the police. ${ }^{31}$ A rule of exclusion is unwarranted unless it will serve to deter improper conduct in the future. ${ }^{32}$ Exclusion when the police could not reasonably anticipate the private citizen's acts would upset the delicate balance that must be maintained between strong public interests in deterring official illegality and convicting the guilty. ${ }^{33}$ At that point, the exclusionary rule would lose its efficacy and become instead a "public nuisance."34

In summary, private action taken in response to a police bulletin warrants a finding of police agency when the activity would not have occurred but for the bulletin and could reasonably have been expected by the police.

29 Cf. W. Seavey, Handbook of the Law of Agency $\$ 18$ (1964).

30 But see Gold v. United States, 378 F.2d 588 (9th Cir. 1967). The police in Gold should have known that their actions would induce the opening of the trunk by the airline employees. The F.B.I. agents, following the activities of Gold and suspecting that he was shipping obscene matter, informed the airline where Gold had delivered for shipment five cartons of "electronic equipment" that they had reason to believe that the waybill was inaccurate and the address of the shipper was nonexistent. The agents then left the airline office. Although the airline supervisor asked, they did not reveal what they suspected were the true contents of the cartons. The airline opened the packages, found obscene film, and called the agents, who also looked at the film. A warrant was not obtained until the following day. The court found the initial search to be private action because the airline had reserved the right to inspect packages when it believed the waybill to be inconsistent with the contents. But the court missed the crucial point that the police knew the bags would be opened and anticipated the finding of contraband.

31 Private citizen searches as in Burdeau are therefore not excluded because of the meager deterrent effect. See, e.g., Note, Seizures By Private Parties: Exchusion in Criminal Cases, 19 Stan. L. Rev. 608, 611 (1967).

32 Id.

33 See generally Amsterdam, Search, Seizure and Section 2255: A Comment, 112 U. PA. L. REv. 378, 389 (1964).

34 Id. 
The Temple and McGrew courts did not follow this standard. In both cases, the police made no specific request that baggage be searched or seized, but merely asked to be informed if the contents of bags were found to contain contraband or if suspicious looking baggage passed through the airlines terminal. Clearly the request was insufficient to create a police agency if by mere observation or exercise of the company's rights ${ }^{35}$ the supervisors observed criminal or suspect behavior. But in each case the supervisors did more than report suspicious behavior: they took action described in Temple as "selfinitiated," ${ }^{36}$ to seize and search suspicious looking trunks or the bags of suspicious looking people. Because these searches for contraband served no airline purpose, the courts should have inferred that the acts on behalf of the police were induced by the bulletins. ${ }^{37}$ Although (unlike the change of locks in Small) the police had no foreknowledge of and thus gave no prior approval to the supervisors' actions, they might reasonably have foreseen that a supervisor requested to report suspect trunks would, seeking his "badge of good citizenship," hold trunks at the terminal for them. Thus, at least sub silentio, the police requested the supervisors to take illegal actions on the state's behalf, and should not be allowed to avoid the consequences of their request by claiming that the acts were purely private.

\section{B. Consequences of Police Agency-Exclusion of Evidence}

If private acts induced by a police bulletin are in fact police acts, then they must conform to fourth amendment requirements if evidence they produce is not to be excluded at trial. ${ }^{38}$ Because the fourth amendment prohibits in most cases searches without warrants, ${ }^{39}$ and because private citizens cannot obtain warrants in California, ${ }^{40}$ evidence gathered in a warrantless search by a citizen-agent should be inadmissible unless the police themselves could have acted without a warrant.

Relying on Carroll $v$. United States, ${ }^{41}$ the Temple court held that a warrant was unnecessary because the evidence sought would vanish with the trunks, due to leave the terminal within the hour. But Carroll is inapposite for airports. Carroll and its progeny rest on the ground that hesitation on the part of the police may lead to the loss or destruction of the evidence. But no such possibility existed in Temple. "Nor was there any likelihood that the lockers would be removed or the contraband destroyed; both footlockers were safely in the custody of

35 See note 25 supra.

$3680 \mathrm{Cal}$. Rptr. at 889.

37 See text accompanying notes 23-25 supra.

38 See, e.g., United States v. Small, 297 F. Supp. 582 (D. Mass. 1969) (excluding the evidence).

39 See Ker v. California, 374 U.S. 23 (1963) ; Carroll v. United States, 267 U.S. 132 (1925).

40 See, e.g., Cal. Penal Code $\$ 1523$ (West 1970) (a warrant is issued in "the name of the people, signed by a magistrate, directed to a peace officer, commanding him to search for personal property, and bring it before the magistrate").

41267 U.S. 132 (1925). 
the airlines." 42 The freight supervisor did not have to withhold the trunks from their flight: he could have called the police to inform them of his suspicions. The police could then have notified the Detroit police that specific trunks were on a particular flight and should be searched and the recipient arrested under a warrant issued in Detroit. ${ }^{43}$ The court's analysis would have been correct had the trunks been en route to a foreign country where they might not have been recoverable. ${ }^{44}$

Even accepting the Temple court's notion that a warrant was not required, the freight supervisor could not seize the trunks unless he had probable cause to act. The information provided by a bulletin may furnish the private citizen with probable cause, but only if it is sufficiently specific to enable a private employee to distinguish between criminal behavior and behavior consistent with either guilt or innocence. Thus bulletins identifying with great specificity a particular trunk which the police have probable cause to seize could also establish probable cause for a private citizen to act.5 A general alert for suspicious-looking trunks would normally be insufficient to give probable cause. In exceptional cases, the police bulletin need not specify a particular item. If the police sufficiently describe a pattern which would usually occur only in conjunction with criminal activity, the private citizen may have probable cause to act.

For example, in Hernandez v. United States, ${ }^{46}$ the Ninth Circuit found that the police had probable cause to believe trunks in an airport contained marijuana when the police had observed for two years previous to the search of Hernandez's trunks a recurring pattern of circumstances connected with a certain smuggling ring. Marijuana was shipped by air from Los Angeles to New York on nonstop commercial flights in the luggage of couriers with Latin American surnames. The couriers traveled first class, but did not make reservations in advance; their luggage was new, expensive, usually bore the brand name "Ventura," and had combination locks; the bags were exceedingly heavy because of the weight of the marijuana; the couriers usually paid the overweight charges in cash with large denomination bills. Airport employees were asked to notify the police if the described pattern appeared. The pattern was exactly reproduced when Hernandez bought a ticket on a flight to New York with two bags 115 pounds over the 40 pound limit. The police were called and on their arrival

42 People v. McGrew, 1 Cal. $3 d$ at 410,462 P.2d at 5, 82 Cal. Rptr. at 476.

43 If the police in one city are hesitant to rely on the police in another, or simply wish to prosecute the offender themselves, perhaps they could instruct the airline employee to detain the baggage while they obtain a warrant.

44 See People v. Craycraft, 1 Cal. App. 3d 947, 82 Cal. Rptr. 154 (1969), in which a freight employee opened a trunk to check for liquor and found what he believed was marijuana. He called the police, but they did not open the trunk because it was scheduled for loading in fourteen minutes. Rather, they notified state narcotics agents that a footlocker was en route from San Diego and contained marijuana. The recipient of the locker in San Francisco was arrested.

45 Cf. Draper v. United States, 358 U.S. 307 (1959).

46353 F.2d 624 (9th Cir. 1965), cert. denied, 384 U.S. 1008 (1966). 
searched the trunks. The court held that probable cause existed: "No one of the indicia drawn from prior incidents of illicit traffic was alone sufficient to justify a reasonable man in the belief that appellant's bags contained contraband, but taken together they rendered it probable." 47 The coincidence of the circumstances was found to be so rare that the possibility of the invasion of the privacy of an innocent individual was unlikely. Had the airline employees themselves conducted the initial search and seizure rather than calling the police, the court might well have determined that probable cause still existed. ${ }^{48}$ Just as the police and airline employees are presumed to be working as a team for the purposes of state action, so may they be considered a team for purposes of probable cause. ${ }^{49}$

The police bulletins in Temple and McGrew did not provide sufficiently specific information to supply probable cause for the searches and seizures. The Temple court found that the bulletin, standing alone, was insufficient to provide the police with probable cause for a search. ${ }^{50}$ The described trunks could have been any of thousands of standard models passing daily through an airlines terminal. The elaborate pattern of behavior described in the Hernandez bulletin was absent. The bulletin in McGrew failed to meet even the level of specificity in the Temple bulletin. ${ }^{51}$ No description of the trunks was provided. The employees were simply to be alert for all suspicious trunks, particularly heavy padlocked footlockers. In neither case was the fourth amendment standard met.

\section{ConcLusion}

Although a necessary and useful tool of law enforcement, police bulletins should serve primarily as a reminder to citizens to notify the police if they find or suspect that they have found evidence of crime. When a bulletin can reasonably be expected to induce a private citizen to act on behalf of the police, his acts should fall within the purview of the fourth and fourteenth amendments. When the citizen-agent's acts are illegal, exclusion of the resulting evidence is necessary to deter the police from using bulletins to induce private citizens to engage in police activities which the police themselves could not perform.

47 Id. at 627.

48 The Hernandes court found that the Government had sustained its burden of proving that it would have been impractical to secure a warrant before the bags were removed. Id. Because the police did not need a warrant, neither did citizenagents.

${ }^{49}$ Cf. Mullaney v. State, 5 Md. App. 248, 246 A.2d 291 (1968) ; People v. Horowitz, 21 N.Y.2d 55, 233 N.E.2d 453, 286 N.Y.S.2d 473 (1967). In both cases the court determined that, even though the arresting policeman did not have probable cause to make an arrest based on his own knowledge and observations, the arrest was valid because he was acting on information or orders from superior police officials, and the police as a whole had probable catuse to arrest. The police were not required to inform the arresting officer of how they obtained the information, but the court required proof of probable cause from the police as a whole.

5080 Cal. Rptr. at $890-91$.

51 See text accompanying notes 4-6 supra. 